\title{
HYPERSENSITIVITY POTENTIAL OF GYNECOLOGICAL DEVICES
}

\author{
Marija Vukelić-Nikolićn ${ }^{1}$ Jasmina Popović ${ }^{2}$, Ljubiša Djordjević3 ${ }^{3}$ Stevo Najman ${ }^{1}$
}

\begin{abstract}
Medical devices encompass an extremely wide range of products used in variety of settings for the diagnosis, prevention, monitoring or treatment of illness or disability. Development of medicine and technology causes constantly increasing number of different medical devices with characteristics corresponding to biomaterials and whose application can lead to development of hypersensitivity reactions. Despite the fact that gynecology is a wide field for biomaterials applications, there are no summarized data about hypersensitivity reactions to gynecological devices. This paper gives an overview of hypersensitivity potential and common clinical manifestations of medical devices that are specifically used in gynecology. Summarizing these data is very important for improvement of current medical practice and also for designing and creating new medical devices.
\end{abstract}

Acta Medica Medianae 2019;58(3):122-127.

Key words: medical devices, biomaterials, gynecology, hypersensitivity reactions

\footnotetext{
${ }^{1}$ University of Niš, Faculty of Medicine, Department of Biology and Human Genetics; Scientific Research Center for Biomedicine, Nišs, Serbia

2University of Niš, Faculty of Medicine, Clinics for Gynecology and Obstetrics, Clinical Center of Niš, Niš, Serbia

${ }^{3}$ University of Niš, Faculty of Science and Mathematics,

Department of Biology and Ecology, Niš, Serbia
}

Contact: Marija Vukelić-Nikolić

Blvd dr Zoran Djindjić 81,18000 Niš, Serbia

E-mail: marija.vukelic.nikolic@medfak.ni.ac.rs

\section{Introduction}

Medical devices encompass an extremely wide range of products used in variety of settings for diagnosis, prevention, monitoring or treatment of illness or disability (1). Development of medicine and technology causes constantly increasing number of different medical devices, with characteristics corresponding to biomaterials. They are most commonly used in orthopedics, maxillofacial surgery, dentistry and vascular surgery as artificial joints, bone plates, bone cement, artificial ligaments and tendons, dental implants, dental filings, heart valves, vascular grafts, pacemaker leads, catheters, drug delivery systems etc. (2). Developments in medical devices are enhanced rapidly by technological advances in diverse fields, such as biomaterials science, bioengineering, electronics, software and IT.

Gynecology and obstetrics are dedicated to women's health and also represent a wide field of biomaterials application. Depending on application, biomaterials used in gynecological practice include: biomaterials used in contraception, biomaterials used for prevention and treatment of infertility, biomaterials that are used during labor and delivery, and biomaterials used in gynecologic surgery (3).

Since biomaterials represent foreign bodies, they can lead to various desirable and undesirable reactions when put in contact with a human organism. One group of adverse and undesired reactions to medical devices represents hypersensitivity reactions.

Despite the fact that gynecology is a wide field for biomaterials applications, there are no summarized data about hypersensitivity potential and hypersensitivity reactions to gynecological devices.

The aim of this paper is to give an overview of hypersensitivity potential and common clinical manifestations of medical devices that are specifically used in gynecology. Summarizing these data is very important for improving current medical practice and also for designing and creating new medical devices.

\section{Biomaterials and hypersensitivity reactions}

According to Second Consensus Conference on Definitions of Biomaterials, biomaterials represent a wide group of natural or artificial "materials that are intended to interface with biological systems to evaluate, treat, augment or replace any tissue, organ or function in the body" (4).

In the preclinical safety biomaterials evaluation, examination of biocompatibility is the first and 
the most important step in biomaterials testing. It includes physico-chemical characterization of biomaterials, evaluation of physiological environment effects on materials and effects of materials on the environment through different aspects. Biodegradability, reactions between the tissue and biomaterials, cytotoxicity, genotoxicity, mutagenicity etc. can be predicted trough different tests validated in vitro and in vivo $(5,6,7,8)$, while the problem of hypersensitivity prediction in pre-clinical phase of biomaterials testing still persists.

Hypersensitivity reactions are very common and extensive health problems, to which physicians from almost every field of medicine face in everyday practice. They are considered as excessive and inappropriate immune responses to presence of an antigen (9). A precondition for developing hypersensitivity reaction is previous sensitization of organism to a specific antigen. Manifestation of the hypersensitivity reaction occurs after re-contact of the organism to the antigen to which it is sensitized.

Clinical manifestations of hypersensitivity reactions are very diverse and many of them are mild, while others can be severe and life-threatening. They can be confined to a small area of the body, or may affect the entire body (10).

The first step towards successful treatment of allergic reactions is determining allergen that provoked hypersensitivity reaction. If the allergen remains undetected, the therapy is symptomatic, and this could further lead to recurrence or persistence of symptoms and further impairment of health and quality of life.

Depending on generated effectors, molecules and mechanisms of their action, four types of hypersensitivity reactions have been clearly defined so far (Type I-IgE mediated hypersensitivity, Type IIcytotoxic-IgG/IgM mediated hypersensitivity, Type III-immune complex mediated-IgG/IgM immune complex and Type IV-delayed hypersensitivity or cell mediated hypersensitivity) (11), while the fifth type is still a subject of speculations (12). Type I and Type IV are the only two types of hypersensitivity reactions which are described as an undesirable response to biomaterials.

For confirming a diagnosis of hypersensitivity reactions, several validated in vitro and in vivo tests are used (skin test prick, in vitro measurement of specific IgE antibodies, cutaneous patch testing, lymphocyte transformation tests etc.) $(13,14,15$, $16,17)$. However, there are no validated in vitro or in vivo methods for screening sensitizing potential in the pre-clinical phase of biomaterials testing so far. The problem of immunologically-based hypersensitivity reactions non-predictability is related to lack of appropriate experimental models, because beside biomaterial composition, individual physiological characteristics of the host organism are of primary importance for development of hypersensitivity reactions (18).

Predicting hypersensitive potential in pre-clinical phase of biomaterials testing is currently based on clinical experience and previously published data about confirmed hypersensitivity reactions to specific components of medical devices.

\section{Gynecological devices}

In 2015, 64 percent (\%) of married women or common-law wives in reproductive age worldwide were using some kind of contraception (UN 2015) (19). Globally, $22.8 \%$ of women using contraception use intrauterine devices (IUDs) (20). Its application includes introducing device into uterus, where it persists several years and where its mechanical and/or chemical action provokes contraceptive effect. Today, two types of IUDs are in use: copper-releasing devices and hormone-releasing devices (21). Both types of IUDs consist of different metallic and polymeric components with different hypersensitivity potential (22).

Nickel, cobalt and chromium are the three most common metals that elicit both cutaneous and extracutaneous allergic reactions from chronic internal exposure (23). In copper releasing devices, approximately $99 \%$ of metal components represent copper, while other metal components include nickel, silver and gold $(24,25)$. Sensitizing capacity of copper sulphate is very low (26), but contact dermatitis and urticaria $(27,28)$ and endometritis and urticaria-angioedema syndrome in women wearing a copper-containing IUDs have been reported (29). It is interesting that allergy to copper sulphate is usually not monovalent, and is commonly associated with other metal allergies, especially with nickel and cobalt sensitization (22); in these reports, only monosenzitisation to copper was confirmed. Besides the fact that nickel in IUDs is usually present in very small quantity, and that there are still no reports on hypersensitivity to this component of IUDs, clinical experience suggests that its vast hypersensitivity potential should not be ignored (23).

Hormone releasing IUDs are made of a polymer frame with a central reservoir containing levonorgestrel. Levonorgestrel, a highly potent second generation progestin, thickens cervical mucus and suppresses endometrial proliferation (preventing decidualization of the stroma). This creates a hostile environment for sperm survival, inhibiting motility and capacitation with the net effect combining to prevent fertilization (30). Polymeric components of hormone releasing IUDs often include polydimethylsiloxane, polyethylene, polypropylene and colloid silica, while metal components often include barium sulphate, iron oxide, silver and copper (24, 25). Chen et al. 2014 (31), reported a case of acute urticaria associated with Mirena ${ }^{\circledR}$ implantation, while both Pereira and Coker 2003, (32) and Karry et al. 2006 (33) reported cases of acute dermatitis related to application of Mirena ${ }^{\circledR}$. No one of the authors analyzed sensitization to specific components of this type of IUDs, but according to the literature data all components of Mirena ${ }^{\circledR}$ possess hypersensitivity potential $(34,35,36,37)$.

Permanent tubal sterilization is a method for irreversible contraception and involves laparoscopic tubal ligation or permanent obstruction of fallopian tubes using tubal devices. For permanent obstruction of fallopian tubes, there are two types of devices with different composition commonly used: inserts composed of polyethylene terephthalate, stainless steel and nickel titanium alloy, and inserts com- 
posed of cured silicone (38). Application of both types of intrauterine devices is accompanied with numerous desirable and undesirable, but frequently present, side effects. There are several reports on hypersensitivity reaction to nickel in women after permanent tubal sterilization by $\operatorname{Essure}^{\circledR}(39,40)$. On the other side, there are no publications about adverse effects to inserts composed of cured silicone in terms of hypersensitivity reactions, which suggests lower hypersensitivity potential compared to the previous type of inserts.

Today, one of the options for long lasting reversible contraception is application of subdermal implantable devices. All currently available implantable contraceptive devices are based on the same principle: progestogen hormone is released from one or more biologically inert tubes that are placed in subdermal layer of upper inner aspect of the woman's non-dominant arm. Biocompatible polymers or copolymers of polydimethyl/ polymethyl vinyl-siloxanes or ethylvinylacetate are used for making biologically inert tubes, to hold the steroid crystals and control the rate of progestogen hormone release (41). Up to date, there are several reports of hypersensitivity reactions to Nexplanon ${ }^{\circledR}(42,43,44)$ in the form of erythaema, oedema and local itching at the site of insertion. Nexplanon ${ }^{\circledR}$ consists of etonogestrel, ethylene vinyl acetate copolymer and barium sulfate, and authors have associated described hypersensitivity reactions to barium sulfate. Hypersensitivity to barium sulphate is extremely rare (2 per million) (43). It is interesting that in most of these cases, before the use of Nexplanon, women used other contraceptive devices (Implanon, Mirena ...). Some authors confirmed specific hypersensitivity reactions to barium-sulphate, while others did not, and at the same time they did not evaluate possibility of hypersensitivity to other components of this implantable device (45).

Induction of labor is artificial initiation of labor before its spontaneous beginning for the purpose of delivery of the feto-placental unit. The rate of labor induction varies by location and institution, but appears to be increasing. If the cervix is unfavorable, cervical ripening is warranted prior to labor induction. Some of current mechanical methods of cervical ripening include application of hygroscopic dilators (e.g. Laminaria, Dilapan-S ${ }^{\circledR}$, Lamicel etc.). Laminaria is natural dilator made from dried seaweed, while Dilapan-S ${ }^{\circledR}$ and Lamicel, are produced from synthetic hygroscopic material. So far, there have been several reports about severe anaphylactic reactions to laminaria $(45,46,47)$ in patients with at least one previous pregnancy terminated with laminaria. The main hypothesis is that the allergen responsible for IgE reactivity with anaphylactic potential was the carbohydrate component of this plant, called laminarin (47). On the other hand, hypersensitivity reactions to hygroscopic dilators were not described in the literature.

Over past decades, the use of synthetic biocompatible materials has become more common in gynecologic surgery. The most common procedures involving use of synthetic meshes are the abdominal sacrocolpopexy, suburethral sling, retropubic urethropexy, adhesion prevention and pelvic floor hernias treatment (49). Chemical components of synthetic meshes are commonly polypropylene, polytetrafluoroethylene (PTFE), expanded PTFE, polyethylene terephthalate, polyglycolic acid, polyglactin 910 (49), oxidized regenerated cellulose, chemically modified sodium hyaluronate and carboxymethylcellulose (50). Some components of synthetic meshes possess hypersensitivity potential, and it is not surprising that there have been reported cases of localized allergic reactions to meshes (51), oxidized regenerated cellulose (52) and systemic reaction to midurethral sling (53). It is interesting that carboxymethylcellulose is widely used as an additive in nonpharmaceutical and pharmaceutical industry as a disintegrant for capsules, tablets and granules (54, 55), and also as a component of synthetic meshes used in gynecological surgery. While there are no records of hypersensitivity to carboxymethylcellulose as a component in devices used in gynecological surgery, there are several reported cases of severe hypersensitivity reaction to carboxymethylcelluse as a component of other medical devices, which suggests it has a vast hypersensitivity potential (54, 55).

\section{Conclusion}

Gynecology represents a wide field for medical devices application. Whether or not, in what way and to what extent the host will respond to presence of devices, depends on composition of biomaterials applied, the site of application, and also it greatly depends on the physiological characteristics of the host organism. Since it is proved that great number of medical devices components possess hypersensitivity potential, physicians should always be careful when planning application of new medical devices. It is necessary to counsel patients about their personal history of hypersensitivity reactions and previous use of medical devices. According to this information and composition of available medical devices for specific use, physicians should make plans about further treatment. Also, in case of hypersensitivity reaction where personal anamnesis and/or medical documentation reveals use of any type of medical devices, hypersensitivity to biomaterials should be always considered as potential cause.

\section{Conflict of interest}

The authors report no conflict of interest.

\section{Acknowledgement}

The paper is a part of the research completed within the project No. III 41017 supported by the Ministry of Education, Science and Technological Development of the Republic of Serbia. 


\section{References}

1. Parvizi N, Woods K. Regulation of medicines and medical devices: contrasts and similarities. Clin Med 2014; 14(1): 6-12. [CrossRef] [PubMed]

2. Tathe A, Ghodke M, Nikalje AP. A brief review: biomaterials and their application. Int J Pharm Pharm Sci 2010; 2(4): 19-23. [CrossRef]

3. Shveiky D, Hants Y. Biomaterials in obstetrics and gynecology. In: Rosen $\mathrm{Y}$, Elman $\mathrm{N}$, editors. Biomaterials Science: An integrated clinical and engineering approach. Boca Raton: CRC Press; 2012. p. 149-64. [CrossRef]

4. Williams DF, Black J, Doherty PJ. Definitions in biomaterials, Second consensus conference on definitions in biomaterials. In: Doherty PJ, Williams RL, Williams DF, Lee AJC, editors. Advances in Biomaterials, Biomaterials-Tissue Interface. vol 10. Amsterdam: Elsevier; 1992. p. 525-33.

5. Najman S, Savic V, Djordjevic $L j$, Ignjatovic $N$, Uskokovic D. Biological evaluation of hydroxyapatite/poly-L-lactide (HAp/PLLA) composite biomaterials with poly-L-lactide of different molecular weights intraperitoneally implanted into mice. Biomed Mater Eng 2004; 14(1): 61-70. [CrossRef] [PubMed]

6. Ignjatović N, Ajduković Z, Savić V, Najman S, Mihailović D, Vasiljević $P$, et al. Nanoparticles of cobalt-substituted hydroxyapatite in regeneration of mandibular osteoporotic bones. J Mater Sci-Mater M 2013; 24(2): 343-54. [CrossRef] [PubMed]

7. Vukelić M, Mitić Ž, Miljković M, Živković J, Ignjatović $\mathrm{N}$, Uskoković $\mathrm{D}$, et al. Apatite formation on nanomaterial calcium phosphate/poly-DL-lactide-co-glycolide in simulated body fluid. ] Appl Biomater Func Mater 2012; 10(1): 43-8. [CrossRef] [PubMed]

8. Vasiljević $P$, Najman $S$, Djordjević Lj, Savić V, Vukelić $\mathrm{MĐ}$, Živanov-Čurlis JZ, et al. Ectopic osteogenesis and hematopoiesis after implantation of bone marrow cells seeded on HAp/PLLA scaffold. Hem Ind 2009; 63(4): 301-7. [CrossRef]

9. Janeway CA Jr, Travers PI, Walport M, Shlomchik MJ. Allergy and Hypersensitivity. In: Immunobiology, the Immune System in Health and Disease. $5^{\text {th }}$ ed. New York: Garland Science; 2001. [PubMed]

10. Bernstein LI, Li JT, Bernstein DI, Hamilton R, Spector $\mathrm{SL}$, Tan $\mathrm{R}$, et al. Allergy diagnostic testing: an updated practice parameter. Ann Allerg Asthma Immunol 2008; 100(Suppl 3): S1-S148. [CrossRef] [PubMed]

11. Gell PGH, Coombs RRA. The classification of allergic reactions underlying disease, In: Coombs RRA, Gell PGH, editors. Clinical Aspects of Immunology. Philadelphia: Blackwell Science; 1963. p. 217-37.

12. Rajan TV. The Gell-Coombs classification of hypersensitivity reactions: a re-interpretation. Trends Immunol 2003; 24(7): 376-9. [CrossRef] [PubMed]

13. Barbaud A, Gonçalo M, Bruynzeel D, Bircher A. Guidelines for performing skin tests with drugs in the investigation of cutaneous adverse drug reactions. Contact Derm 2001; 45(6): 321-8. [CrossRef] [PubMed]

14. Bousquet J, Michel F-B. In vivo methods for study of allergy: skin tests, techniques, and interpretation. In: Middleton E Jr, Reed CE, Ellis EF, Adkinson NF Jr, Yunginger JW, Busse WW, editors. Allergy: Principles and Practice. 4th ed. St. Louis: CV Mosby; 1993. p. 573-594.

15. Chung BY, Kim HO, Park CW, Lee CH. Diagnostic usefulness of the serum-specific IgE, the skin prick test and the atopy patch test compared with that of the oral food challenge test. Ann Dermatol 2010; 22 (4): 404-11. [CrossRef] [PubMed]

16. Granchi D, Cenni E, Giunti A, Baldini N. Metal hypersensitivity testing in patients undergoing joint replacement. A systematic review. J Bone Joint Surg $\mathrm{Br}$ 2012; 94 (8): 1126-34. [CrossRef] [PubMed]

17. Valentine-Thon E, Muller K, Guzzi G, Kreisel S, Ohnsorge P, Sandkamp M. LTT-MELISA ${ }^{\circledR}$ is clinically relevant for detecting and monitoring metal sensitivity. Neuro Endocrinol Lett 2006; 27(Suppl 1): 17-24. [CrossRef] [PubMed]

18. Galbiati V, Papale A, Kummer E, Corsini E. In vitro models to evaluate drug-induced hypersensitivity: potential test based on activation of dendritic cells. Front Pharmacol 2016; 7: 1-10. [CrossRef] [Pubmed]

19. United Nations, Department of Economic and Social Affairs, Population Division. Trends in Contraceptive Use Worldwide 2015. (ST/ESA/SER.A/349). 2015 [CrossRef] [PubMed]

20. Buhling KJ, Zite NB, Lotke P, Black K. Worldwide use of intrauterine contraception: a review. Contraception 2014; 89(3): 162-73. [CrossRef] [PubMed]

21. Curtis KM, Tepper NK, Jatlaoui TC, Berry-Bibee $E_{\text {, }}$ Horton LG, Zapata LB, et al. U.S. Medical Eligibility Criteria for Contraceptive Use 2016. MMWR Recomm Rep 2016; 65(3): 1-103. [CrossRef] [PubMed]

22. Hallab N, Merritt K, Jacobs JJ. Metal sensitivity in patients with orthopaedic implants. J Bone Joint Surg Am 2001; 83(3): 428-36. [CrossRef] [PubMed]

23. Basko-Plluska JL, Thyssen JP, Schalock PC. Cutaneous and systemic hypersensitivity reactions to metallic implants. Dermatitis 2011; 22(2): 65-79. [CrossRef] [PubMed]

24. Bhathena RK, Guillebaud J. Intrauterine contraception: an update. J Obstet Gynaecol 2008; 28(3): 2625. [CrossRef] [PubMed]

25. Luukkainen $T$, Allonen $H$, Nielsen $N-C$, Nygren K-G, Pyörälä T. Five years' experience of intrauterine contraception with the Nova-T and the Copper- T-200. Am J Obstet Gynecol 1983; 147(8): 885-92. [CrossRef] [PubMed]

26. Fage SW, Faurschou A, Thyssen JP. Copper hypersensitivity. Contact Dermatitis 2014; 71(4): 191-201. [CrossRef] [PubMed]

27. Karlberg AT, Boman A, Wahlberg JE. Copper-a rare sensitizer. Contact Dermatitis 1983; 9 (2): 134-9. [CrossRef] [PubMed]

28. Romaguera C, Grimalt F. Contact dermatitis from a copper-containing intra-uterine device. Contact Dermatitis 1981; 7(3): 163-4. [CrossRef] [PubMed]

29. Purello-D'Ambrosio F, Ricciardi L, Isola $S$, Gangemi $S$, Cilia M, Levanti C, et al. Systemic contact dermatitis to copper-containing IUD. Allergy 1996; 51(9): 658-9. [CrossRef] [PubMed]

30. ESHRE Capri Workshop Group. Intrauterine devices and intrauterine systems. Hum Reprod Update 2008; 14(3): 197-208. [CrossRef] [PubMed]

31. Chen X, Wu X, Zhu H. Acute urticaria as a side effect of the Mirena ${ }^{\circledR}$ (levonorgestrel-releasing intrauterine system): a case report. BMC Res Notes 2014; 7: 209. [CrossRef] [PubMed]

32. Pereira $A$, Coker A. Hypersensitivity to Mirena-a rare complication. J Obstet Gynaecol 2003; 23(1): 81-92. [CrossRef] [PubMed]

33. Karri K, Mowbray D, Adams S, Rendal JR. Severe seborrhoeic dermatitis: Side-effect of the Mirena intra- 
uterine system. Eur J Contracept Reprod Health Care 2006; 11(1): 53-4. [CrossRef] [PubMed]

34. Al-Qattan MM, Kfoury H. A delayed allergic reaction to polypropylene suture used in flexor tendon repair: case report. J Hand Surg Am 2015; 40(7): 1377-81. [CrossRef] [PubMed]

35. Ben Fredj N, Ben Fadhel N, Chaabane Al, Chadly Z, Ben Romdhane $H$, Boughattas $A$, et al. Colloidal silicainduced hypersensitivity: myth or reality. Int J Clin Pharm 2016; 38(1): 7-9. [CrossRef] [PubMed]

36. Marcus DM. An analytical review of silicone immunology. Arthritis Rheum-Us 1996; 39(10): 1619-26. [CrossRef] [PubMed]

37. Shah S, Prematta T, Adkinson NF, Ishmael FT. Hypersensitivity to polyethylene glycols. J Clin Pharmacol 2013; 53(3): 352-5. [CrossRef] [PubMed]

38. Yoong W, Lodhi W, Hall R, Balachandren N, Aujla B. Is it time to abandon traditional laparoscopic sterilisation? J Obstet Gynaecol 2011; 31(4): 281-2. [CrossRef] [PubMed]

39. Al-Safi Z, Shavell VI, Katz LE, Berman JM. Nickel hypersensitivity associated with an intratubal microinsert system. Obstet Gynecol 2011; 117(2 Pt 2): 461-2. [CrossRef] [PubMed]

40. Bibas N, Lassere J, Paul C, Aquilina C, GiordanoLabadie F. Nickel-induced systemic contact dermatitis and intratubal implants: the baboon syndrome revisited. Dermatitis 2013; 24(1): 35-6.

[CrossRef] [PubMed]

41. Croxatt HB. Progestin implants for female contraception. Contraception 2002; 65(1): 15-9. [CrossRef] [PubMed]

42. Serati M, Bogani G, Kumar S, Cromi A, Ghezzi F. Delayed-type hypersensitivity reaction against Nexplanon ${ }^{\circledR}$. Contraception 2015; 91(1): 91-2. [CrossRef] [PubMed]

43. Pedroso C, Martins I, Palma F, Machado AI. Implant site Nexplanon reaction? BMJ Case Reports 2015; bcr2014206256. [CrossRef] [PubMed]

44. Chaudry F. Adverse Reaction to Nexplanon (R). J Fam Plan Reprod Health Care 2013; 39(3): 231-2. [CrossRef] [PubMed]

45. Sullivan M. Allergy to Nexplanon ${ }^{\circledR}$. J Fam Plan Reprod Health Care 2012; 38: 272. [CrossRef] [PubMed]
46. Sierra T, Figueroa MM, Chen KT, Lunde B, Jacobs A. Hypersensitivity to laminaria: a case report and review of literature. Contraception 2015; 91(4): 353-5. [CrossRef] [PubMed]

47. Nguyen MT, Hoffman DR. Anaphylaxis to laminaria. J Allergy Clin Immunol 1995; 95(1): 138-9. [CrossRef] [PubMed]

48. Chanda M, Mackenzie P, Day JH. Hypersensitivity reactions following laminaria placement. Contraception 2000; 62(2): 105-6. [CrossRef] [PubMed]

49. Iglesia CB, Fenner DE, Brubaker $L$. The use of mesh in gynecologic surgery. Int Urogynecol J 1997; 8(2): 105-15. [CrossRef] [PubMed]

50. González-Quintero VH, Cruz-Pachano FE. Preventing adhesions in obstetric and gynecologic surgical procedures. Rev Obstet Gynecol 2009; 2(1): 38-45. [CrossRef] [PubMed]

51. Cosson M, Debodinance P, Boukerrou M, Chauvet MP, Lobry $P$, Crépin $G$, et al. Mechanical properties of synthetic implants used in the repair of prolapse and urinary incontinence in women: which is the ideal material? Int Urogynecol J 2003; 14(3): 169-78. [CrossRef] [PubMed]

52. Foti C, Bonamonte D, Conserva A, Angelini G. Allergic contact dermatitis to regenerated oxidized cellulose contained in a matrix employed for wound therapy. Contact Dermatitis 2007; 57: 47-8. [CrossRef] [PubMed]

53. Iyer J, Askern A, Rane A. A systemic allergic reaction to a mid-urethral sling. Aust Nz J Obstet Gyn 2013; 53(3): 322-34. [CrossRef] [PubMed]

54. Muroi N, Nishibori M, Fujii T, Yamagata M, Hosoi S, Nakaya N, et al. Anaphylaxis from the carboxymethylcellulose component of barium sulfate suspension. $\mathrm{N}$ Engl J Med 1997; 337: 1275-7.

[CrossRef] [PubMed]

55. Mumoli N, Cei M, Luschi R, Carmignani G, Camaiti A. Allergic reaction to Croscarmellose sodium used as excipient of a generic drug. QJM: An International Journal of Medicine 2011; 104(8): 709-10.

[CrossRef] [PubMed] 


\title{
HIPERSENZITIVNI POTENCIJAL GINEKOLOŠKIH MEDICINSKIH SREDSTAVA
}

\author{
Marija Vukelić-Nikolić1 ${ }^{1}$ Jasmina Popović2 ${ }^{2}$ Ljubiša Đorđević3 $^{3}$, Stevo Najman ${ }^{1}$
}

\begin{abstract}
${ }^{1}$ Univerzitet u Nišu, Medicinski fakultet, Katedra za biologiju i humanu genetiku; Naučno-istraživački centar za biomedicinu, Niš, Srbija

${ }^{2}$ Univerzitet u Nišu, Medicinski fakultet, Klinika za ginekologiju i akušerstvo, Klinički centar Niš, Niš, Srbija

${ }^{3}$ Univerzitet u Nišu, Prirodno-matematički fakultet, Odeljenje za biologiju i ekologiju, Niš, Srbija
\end{abstract}

Kontakt: Marija Vukelić-Nikolić

Bulevar dr Zorana Đinđića 81, 18000 Niš, Srbija

E-mail: marija.vukelic.nikolic@medfak.ni.ac.rs

Medicinska sredstva obuhvataju izuzetno širok spektar proizvoda koji se koriste u cilju postavljanja dijagnoze, prevencije, praćenja i lečenja bolesti ili invaliditeta. Razvoj medicine i tehnologije uzrokuje konstantno povećanje broja i upotrebe različitih medicinskih sredstava čije karakteristike odgovaraju biomaterijalima i koja istovremeno mogu da dovedu do razvoja hipersenzitivnih reakcija. Uprkos činjenici da je ginekologija široko polje primene biomaterijala, nema sumiranih podataka o hipersenzitivnim reakcijama na ginekološka medicinska sredstva. Ovaj rad daje pregled hipersenzitivnog potencijala i uobičajenih kliničkih manifestacija hipersenzitivnih reakcija na medicinska sredstva koja se specifično koriste u ginekologiji. Sumiranje ovih podataka veoma je važno kako za unapređenje trenutne medicinske prakse, tako i za poboljšanje karakteristika postojećih i dizajniranje novih medicinskih sredstava.

Acta Medica Medianae 2019;58(3):122-127. reakcije

Ključne reči: medicinska sredstva, biomaterijali, ginekologija, hipersenzitivne 